\title{
Evaluation of Islamic Education Learning at Hidayatul Mustafidin High School
}

\author{
Ashif Az Zafi* ${ }^{* 1}$, Anik Sri Widayati ${ }^{* 2}$ \\ IAIN Kudus, Kudus, Indonesia \\ $\underline{\text { ashifazzafi@iainkudus.ac.id, }}{ }^{2}$ Widayatia18@gmail.com
}

\begin{abstract}
This study aims to describe how the evaluation of Islamic Religious Education learning at SMA Hidayatul Mustafidin. The strategy used in implementing the learning evaluation and evaluation results of learning Islamic Islamic Religious Education learning at SMA Hidayatul Mustafidin. In the research process the author uses a qualitative approach. The data collection is done obsevation, interviews, and literature studies. the results of the research can be obtained that application of the evaluation of Islamic Religious Education learning at SMA Hidayatuk Mustafidin in addition to written methods such as daily tests, midterm assessments, end of semester assessments, also seen the behavior of students so that when students behave less well, guidance will be given. It can be seen from the student activity forum such as tambourine, scouting, and student council activities. The impact obtained by students is expected to be able to behave well.
\end{abstract}

Keywords: Evaluation; Learning; Islamic Education.

\section{Introduction}

Sociologically and psychologically, religious education is critical and needed in life. Religious education is believed to contribute significantly to the development of the nation's children towards of a civilized and respectable character or personality. Then Islamic Religious Education in schools is

* Fakultas Ilmu Tarbiyah dan Keguruan Universitas Islam Negeri Sunan Kaliaga, Jl. Laksda Adisucipto Yogyakarta 55281, Daerah Istimewa Yogyakarta Tepl: (0274) 519709

* Fakultas Ilmu Tarbiyah dan Keguruan Universitas Islam Negeri Sunan Kaliaga, Jl. Laksda Adisucipto Yogyakarta 55281, Daerah Istimewa Yogyakarta Tepl: (0274) 519709 
expected to foster personal obedience and social obedience. Therefore, it is so important that effective learning becomes a means of compiling and improving student skills, for this reason, full assessment activities are needed to obtain information on the achievement of goals and the progress of a series of learning activities (Rivai and Sudjana, 2004).

So far, based on the results of interviews with the deputy head of curriculum, the application of the assessment of Islamic Religious Education is still not perfect. Because in evaluations there are often many educators how to complete assessment of student learning outcomes not systematically and sequentially from time to time and the aspects that are assessed for learning outcomes are mostly taken from a cognitive perspective only, so that the goals in education that have been prepared have not been implemented properly, or the teacher does not have an impressive record or interest so that students do not take it seriously because they feel they are not being monitored and do not control the development of their competence, in the end the most complicated problem in a learning system is the lack of practical assessment. For this reason, the importance of assessing the subject of Islamic Religious Education (PAI), a researcher wants to know things related to the application of the assessment carried out including preparation, implementation and results and how the feedback is given (Saifulloh and Safi'i 2017).

There are three interesting studies to review regarding the evaluation of Islamic Religious Education learning at SMA Hidayatul Mustafidin. First, based on the results of research from the American Journal of Educational Research entitled Evaluation Model for Islamic Education Learning in Junior High School and its Significance to Students' Behaviors, it is stated that the discussion of the evaluation of Islamic Religious Education on average is almost the same regarding children's daily behavior. In addition, learning outcomes can be seen from the scores obtained during the test. The assessment of the Islamic Education Religion for learning outcomes must be comprehensive which includes aspects of attitude, knowledge and skills. Religion of Islamic education has a basic framework of thought which becomes a reference for all educational practices in all aspects of human life. The basic framework is built from three basic concepts of devotion, faith 
and good deeds. This basic concept forms the core of Islamic teachings which must serve as the basis for the structure of any system. These three basic teachings have been developed by scholars into three studies of the concept of faith related to issues of belief in God, laws related to behavioral problems, good deeds, and good deeds related to behavior.

The three basic concepts are related to synergy and harmonious relationship to produce harmony and balance in the four types of relationships. The first is the relationship between humans and their creator in relation to the extent to which humans have fulfilled their responsibilities to the Creator. The second is the relationship between humans in which no one should do it so that it will hurt others. The third is the relationship between humans and animals and an environment where no one will have an impact on the damage. The fourth is the relationship between humans and themselves, where humans must behave themselves properly (Kartowagiran and Maddini 2015).

Second, from the Al-Ta lim Journal entitled A Learning Process Evaluation Model for the Integrated Islamic Elementary School states that in Law no. 20 of 2003 regarding the National Education System paragraph 1 has stated that education is a conscious and planned effort to realize the learning process and learning situation so that learning students are able to actively develop their potential so that they are able to achieve their spiritualreligious strength, personality, intelligence, self-control. , glory and skills that will be needed for themselves, their community, file, nation and country. Review the meaning of education in the above statement. The researchers found several key words were active learning, personality, spiritual religious, nobility and skills. And several studies have looked at the correlation between teacher outcomes in evaluating students. However, the positive effect of an educator's evaluation cannot be felt except in certain conditions. As is the case for broader statements about leadership attendance in schools, teaching staff are self-employed and receive training to improve teacher evaluation. Based on these studies, first, to produce appropriate assessment or evaluation instruments that might be implemented to evaluate learners. second, identify the effectiveness of the evaluation instrument it was developed. Third, identify the descriptions and criteria in the 
evaluation results that have been carried out. This was done so that in evaluating students it could run well and accordingly (Wahyuningsih 2016).

Third, from the journal Educational Research and Evaluation entitled An Evaluation Model of Islamic Learning Education Program in Madrasah Aliyah states that people's lives are faced with problems related to decreasing behavior and ethics in social life. Both at school (Madrasah), family environment, and the environment around it. This suggests a stronger interest in adjusting education implementation. Islamic religious education at this time has had many types of sharp criticism because of its inability to solve important problems in life. Therefore, religious education must get general attention in building the character and morals of the nation. Learning Islamic Religious Education in schools is very dependent on an educator because the teacher is one of the components that has an important role as role models and administrators, facilitators and even motivators for students. Mardapi explained that evaluation in the field of education in terms of the target can be divided into two parts, namely macro evaluation and micro evaluation. Evaluation of macro targets, namely education programs in general, programs that are planned to improve an education. Meanwhile, micro evaluation is often used at the class level. For this reason, the more important evaluation of the learning program is how Islamic education learning can be evaluated competently as long as it is accurate and complete information, it requires a program evaluation model that specifically describes how to evaluate the learning being carried out. For this reason, the assessment is very important to do in learning Islamic Religious Education (Anidi 2017).

Type of research uses field research using a descriptive qualitative approach, namely research conducted by collecting some data obtained by researchers in accordance with the phenomena that occur (Gunawan 2013). This method will describe what actually happened in the field. Data collection techniques using interview techniques, observation (observation), and research documentation. This research is about the evaluation of Islamic Religious Education learning at SMA Hidayatul Mustafidin. The data analysis technique uses the stages of data 
collection, data reduction, data presentation and conclusion drawing.

\section{Discussion}

\section{Learning Evaluation of Islamic Religious Education}

In English the word evaluation means evaluation, alTaqdir comes from Arabic, while the word assessment comes from Indonesian (Hidayat and Asyafah 2019). The definition of evaluation is as an orderly and continuous process to unify, interpret, describe, and provide information about a program so that it can be used as a basis for making decisions, compiling a policy or compiling the next program (FACHRURI 2017). Evaluation is also defined as a process of collecting data to ascertain the extent, which part, and in terms of educational goals, an assessment process does not only measure the extent to which objectives are achieved, but is used to make decisions (Sukardi 2014).

Whereas learning is a process of collaboration between educators and students in utilizing all existing potential and resources, both potential that comes from within the students themselves such as interests, talents and basic abilities possessed including learning styles and potentials that exist outside of students such as means, environment, and learning resources as an effort to achieve certain learning goals (Sanjaya 2010). For this reason, learning evaluation is the process of learning assessment activities made by educators so that they can be used as a basis for arranging activities, making decisions, and subsequent learning programs.

The purpose of learning assessment is a way to measure program achievement, such as measuring the extent to which a policy can be applied. There are two types of evaluation objectives, namely general goals and specific objectives (Arikunto and Jabar 2004). The general objectives are directed at the program as a whole while the specific objectives are directed at each of the factors. Evaluation for one particular purpose is important, but may not be useful for another. Therefore, educators must identify several types of assessment objectives and the requirements that must be met so that they can plan and carry out the assessment. 
The main objective of the pursuit evaluation is the first, obtained from a number of data or information about the meaning, value and benefits of learning activities. second, to determine the overall quality of learning, including the implementation stage of the learning process, planning the learning process, and evaluating learning outcomes. if the main objective of the process assessment activity has been realized, that the results can be functioned and directed for various purposes. Several functions of process appraisal are intended for the following purposes:

a. Diagnostic and learning improvement, namely the results of the process assessment are needed to be the basis for diagnosing the strengths and weaknesses of the learning process and their reasons. From the results of this diagnosis, an educator carries out the development of the learning process to improve the quality of the learning process and student learning outcomes.

b. For evaluating the performance of an educator, the process evaluation carried out by the teacher's performance assessor is in the school, the results can be used as a basis for evaluating the performance of an educator in the preparation, realization, and evaluation of learning.

c. For coaching the performance of an educator. Assessment of the learning process carried out by the principal or school supervisor in the form of learning supervision, the result is the basis for overcoming and implementing teacher performance coaching programs in the preparation, implementation and evaluation of learning.

The evaluation process carried out by the assessor, the principal is the most important part for educator feedback. through the assessment process, an educator will get information about the improvement of the learning process that he is carrying out. From the results of the evaluation of the process, an educator will be able to determine how the learning process needs to be carried out.

Tayar Yusuf argues that Islamic Religious Education is a conscious effort of the older generation to transfer experiences, skills, knowledge, skills to the younger generation so that one day he can become a Muslim man, fear Allah SWT, 
have noble character, and a good personality, live and practice the teachings of Islam in his life (FAJRI 2019).

The formation of a Muslim person through the teachings of Islamic Religious Education, a Muslim contains personal namely as a full protector of the teachings of Allah Almighty and His Messenger. However, achieving Muslim education will not be carried out or fostered unless with education and teaching, guiding or fostering Muslim personalities is an obligation. Because the Muslim person can not be realized or achieved except with education. For this reason, education is mandatory in the view of Islam (Yasyakur 2017). In an activity it will end when the goal has been realized or accomplished, Islamic Religious Education in schools aims to foster and increase faith through the provision of knowledge and practice of students regarding Islam so that they become Muslim humans who continue to develop in terms of piety, belief, nation, and religion. state, in order to continue to a higher level of education (Andayani and Majid 2004).

There are two kinds of Islamic religious education learning at SMA Hidayatul Mustafidin in the form of evaluation. First, learning assessment by test. The so-called test is a series of questions used to measure the intelligence, knowledge, abilities or talents possessed by groups or individuals. In giving assignments to students by giving a series of questions. For lesson questions (pre-test) is given before the lesson as an initial assessment or given after the lesson (post-test) as a final assessment. The questions arranged by an educator are adjusted to the student's ability level. From the results of a test can be used as a benchmark for carrying out cognitive assessments or evaluations as well as being the basis for conducting continuous assessments.

Second, non-test learning evaluation. Non-test learning evaluation is to obtain an overview assessment related to student characteristics, behavior, or personality. Observation with statements, observations made before, during, middle, and end, this is a form of non-test learning evaluation. The results of the observations can be used in affective and psychomotor assessments. Affective assessment, for example, there are statements that lead to attitudes that indicate the 
development of students in terms of discipline, diligence, sincerity, hard work, and so on. for psychomotor assessments such as statements that direct an educator to find out a student's ability to obey the teacher's orders, willingness to help friends, presenting assignments and so on (Ismanto 2014).

2. Implementation of Learning Evaluation in Islamic Religious Education Materials at Hidayatul Mustafidin High School

Implementation of Islamic Religious Education is a way, a process, in carrying out an action (draft decision) of Islamic Religious Education. In learning, especially religious learning, it should be in the form of explaining the values contained in the curriculum and correlating them in a reality that exists around students. What must be carried out by an educator in teaching includes three stages, namely the preinstructional stage, the instructional stage and the follow-up evaluation stage.

a. Pre-instructionalinstructional

Stage the pre-stage is an educator, there must be stages that are taken. When he started the learning and teaching process. From this stage, it aims to reveal the students' responses to the material they have received, and with the lessons that day it is hoped that the learning conditions of students will be fostered. In a physical sports education, this activity is called a problem. There are several activities that can be carried out by an educator or by students at this stage:

1) The teacher records who is absent or absent from attending the lesson and asks about the attendance of students. The presence of students in teaching can be used as a measure of the ability of teachers to teach. The absence of students is not always related to the condition of the student concerned (sick, skipping class, lazy, etc.) but it can also occur because teaching and teachers are not pleasant, their attitude is disliked by students, or because the teacher's actions at the time of teaching are considered detrimental students (unfair assessment, inferiority complex, giving punishment that causes frustration, etc.). 
2) Students are given questions, where is the discussion of the previous lesson. Therefore, the teacher can find out whether there is a student's learning habit at home, at least the students' readiness to face the lesson that day.

3) The teacher asks questions to students in the class or certain students about the lesson material that has been given previously. In order to know where the understanding of the material has been.

4) Gives students the opportunity to ask questions about lesson material that they have not mastered from previously implemented teaching.

5) Repeating the previous lesson material (previous lesson material) is brief but includes all aspects of material that have been previously discussed. This is done as a basis for lessons to be discussed the following day, as well as an effort to create student learning conditions. The purpose of this stage is that the students' responses are expressed again on the material they have received, and foster learning conditions in relation to the lessons that day. The way of teaching the pre-instructional stage in the strategy or teaching method is similar to the warmup activity in sports. This will affect the success of a student.

b. Instructional

Stage The instructional stage is the stage of providing lesson material that has been prepared by an educator beforehand. In general, several activities can be identified as follows:

1) Students will be explained on the teaching goals that students must achieve.

2) The subject matter to be discussed that day must be written down which is taken from the source book that has been prepared previously.

3) The subject matter that has been written will be discussed again. The material can be pursued in two ways, namely: first, the discussion starts from an overview of the teaching material to a more specific topic. Second, starting from specific topics to general topics. 
4) Students must be given questions or assignments to find out the level of understanding of each subject that has been discussed. For that, each subject discussed should be given concrete examples.

5) In teaching, it is necessary to use tools to clarify the discussion of each subject matter.

6) Conclude the results of the discussion from the subject matter. This conclusion is made by an educator and the points should be written on the board for the students to record. conclusions can also be made by the teacher with students, even if possible it is completely left to the students.

c. Evaluation and Follow-Up

Stage The third stage is the evaluation or assessment stage and follow-up in learning activities. This stage aims to determine the level of success of the second stage (instructional).

The three stages discussed above constitute a series of integrated activities, inseparable from one another. Teachers are required to be able and able to manage time and activities flexibly, so that the three series are accepted by students as a whole. Herein lies the professional skills of an educator in implementing teaching strategies. Teaching ability as described in the description above is theoretically easy to master, but in practice it is not as easy as described. It is only with practice and habit of learning that this faculty can be acquired (Zulaekha 2015).

\section{Results of Learning Evaluation of Islamic Religious} Education Materials at Hidayatul Mustafidin High School Learning

Outcomes are the abilities that learners have after receiving their learning experiences. In essence, the learning outcomes of students are changes that include affective, cognitive and psychomotor fields that are oriented towards teaching and learning poses experienced by students (Sudjana 2014). According to Sudjana, learning outcomes are a process that is marked by changes in a person. Change as a result of the learning process is shown in various forms such as changes in 
behavior, attitudes, and changes in other aspects that exist in the learning individual.

Islamic Religious Education (PAI) in Indonesia as a subsystem of National Education, which has the same role as education but generally, in the process of developing the National. Islamic religious education has a very important role in the framework of the formation of the whole Indonesian human being, namely people who believe and fear Allah Almighty.

So it can be said that Islamic Religious Education is an effort to inherit the values that must be held by Muslims in their lives in accordance with the practices and beliefs taught by the Prophet Muhammad. This opinion says that Islamic Religious Education is defined as a conscious effort to prepare students to understand, believe in, appreciate, and secure the teachings of Islam in relations between religious communities in society to realize National unity.

According to Muhaimin, Islamic Religious Education is the name of the system, namely an Islamic education system, which has components that as a whole support the realization of a perfect or ideal Muslim figure. Islamic education is education whose theories are compiled based on the Koran and Hadith (Tohirin 2008).

So, the learning outcomes of Islamic Religious Education are abilities obtained by students after participating in Islamic religious education learning activities, both in terms of cognitive, affective and psychomotor so that the individual in living his life is based on the Koran and hadiths as a source of Islamic education.

According to Mr. Mohammad Rifa; $\mathrm{i}^{1}$ for students in learning Islamic Religious Education learning can master the material from beginning to end which includes reading, practicing the material being taught and understanding or understanding what has been taught in full, understanding the

Anik Sri Widayati, Wawancara Oleh Mohamad Rifa'i. Di SMA Hidayatul Mustafidin Pada Tanggal 21 April , 2021. 
meaning and translating, will but in some cases there are still difficulties in the subject matter. Therefore, students need more attention to improve the results that have been obtained. Finally, indirectly students who do not understand or do not understand in a lesson are mostly students who do not or do not pay attention when an educator delivers the material or the students' lack of learning.

For students whose overall final score meets the standard of meaning assessment, they are allowed to continue the lesson in the next material. Meanwhile, students whose final scores have not met the standard value set by the educator with a limit of $65 \%$ will be given such as enrichment, remedies, or given additional lessons until students are deemed to have mastered the material.

Based on the data on the results obtained or achieved, it can be seen that all students for the report card scores get an average total value above the limit of the assessment standards or the specified criteria. So, this shows that the learning process of Islamic Religious Education (PAI) is going well. The standard of assessment for Islamic Religious Education (PAI) subjects for all aspects is determined by an educator with value limits. Therefore, for students whose report card scores are above the assessment standards, they are considered capable and mastering the material that has been taught by an educator.

\section{Conclusion}

Based on the results of research and discussion of the evaluation of Islamic Religious Education learning at Hidayatul Mustafidin High School. Then conclusions can be drawn. At the planning stage, the evaluation has been carefully formulated. This can be seen from the tests and non-tests to evaluate such as from daily tests, midterm assessments, end-semester assessments as well as the behavior of students and the planned learning implementation time which in detail includes the implementation time, the purpose of the evaluation, as well as the methods and types of evaluation used. will be used. In terms of time, it is based on the academic calendar for one semester. Meanwhile, planning methods and types see the relevance of the evaluation tool and the 
aspects assessed include cognitive, affective and psychomotor aspects.

In general, the results of the evaluation of Islamic Religious Education learning show good because the final results obtained by students are above the minimum passing threshold of $65 \%$. The results of daily tests and assignments aim to determine the level of mastery of student teaching materials and as a reference for educators to improve the quality of the teaching and learning process. While the evaluation results from the final semester assessment are used to determine the level of learning success for one semester. The results of this evaluation or assessment are not only beneficial for an educator but also useful for students as a basis for improving achievement, and are also useful for parents and schools themselves.

\section{References}

Andayani, Dian, and Abdul Majid. 2004. "Pendidikan Agama Islam Berbasis Kompetensi." Bandung: Remaja Rosdakarya.

Anidi, Anidi. 2017. "An Evaluation Model of Islamic Learning Education Program in Madrasah Aliyah." Jurnal Penelitian dan Evaluasi Pendidikan 21(1): 21-33.

Arikunto, Suharsimi, and Cepi Safruddin Abdul Jabar. 2004. “Evaluasi

Program Pendidikan Pedoman Teoritis Praktis Bagi Praktisi Pendidikan." Jakarta: Bumi Aksara.

Fachruri, Nim. 2017. “Evaluasi Pembelajaran PAI Di SMP Negeri Gongseng Satu Atap Kecamatan Randudongkal Kabupaten Pemalang."

Fajri, Mathla'il. 2019. “Pelaksanaan Pendidikan Agama Islam Dalam Pembinaan Akhlak Pada Siswa SDN 1 Karang Maritim Kec. Panjang Kota Bandar Lampung (Dari Segi Metode Dan Evaluasi Pembelajaran Serta Pembinaan Akhlak)." 
Gunawan, Imam. 2013. "Metode Penelitian Kualitatif." Jakarta: Bumi Aksara 143.

Hidayat, Tatang, and Abas Asyafah. 2019. “Konsep Dasar Evaluasi Dan Implikasinya Dalam Evaluasi Pembelajaran Pendidikan Agama Islam Di Sekolah." Al-Tadzkiyyah: Jurnal Pendidikan Islam 10(1): 159-81.

Ismanto, Ismanto. 2014. “Evaluasi Hasil Belajar Pendidikan Agama Islam (PAI)." Edukasia: Jurnal Penelitian Pendidikan Islam 9(2).

Kartowagiran, Badrun, and Harsul Maddini. 2015. “Evaluation Model for Islamic Education Learning in Junior High School and Its Significance to Students' Behaviours." American Journal of Educational Research 3(8): 990-95.

Paradigma Pendidikan Islam: Upaya Mengefektifkan Pendidikan Agama Islam Di Sekolah. 2001. Remaja Rosdakarya. https://books.google.co.id/books?id=OwGSAAAACAAJ.

Rivai, Ahmad, and Nana Sudjana. 2004. “Dasar-Dasar Proses Belajar Mengajar." Bandung: Sinar Baru Algensindo.

Reni, Romadhona. 2018. Implementation of Learning Evaluation of Islamic Religious Education in Bandar Lampung. Thesis, UIN Raden Intan Lampung.

Saifulloh, Ahmad, and Imam Safi'i. 2017. "Evaluasi Pembelajaran Mata Pelajaran Pendidikan Agama Islam Di Sekolah Menengah Pertama (Studi Kasus Di SMPN 2 Ponorogo)." Educan: Jurnal Pendidikan Islam 1(1).

Sanjaya, Wina. 2010. “Perencanaan Dan Desain Sistem Pembelajaran Cet III." Jakarta. Kencana. 
Sri Widayati, Anik. interview by Mohamad Rifa'i. Hidayatul Mustafidin High School. 21 April , 2021.

Sudjana, Nana. 2014. "Penilaian Hasil Proses Belajar Mengajar."

Sukardi, S. 2014. "Evaluasi Program Pendidikan Dan Pelatihan." Jakarta: Bumi Aksara.

Tohirin, M Pd. 2008. "Psikologi Pembelajaran Pendidikan Agama Islam Berbasis Integrasi Dan Kompetensi, Jakarta: PT." Raja Grafindo Persada.

Wahyuningsih, Retno. 2016. “A Learning Process Evaluation Model for the Integrated Islamic Elementary School." Al-Ta lim Journal 23(3): 201-13.

Yasyakur, Moch. 2017. "Strategi Guru Pendidikan Agama Islam Dalam Menanamkan Kedisiplinan Beribadah Sholat Lima Waktu." Edukasi Islami: Jurnal Pendidikan Islam 5(09): 35.

Zulaekha, Umi. 2015. “Implementasi Pembelajaran Pendidikan Agama Islam (PAI) Bagi Narapidana Anak Di Lembaga Pemasyarakatan Anak Kutoarjo Kabupaten Purworejo Jawa Tengah."

Zulaekha, Umi. 2015. Implementation of Islamic Religious Education (PAI) Learning for Child Prisoners in Kutoarjo Child Prison, Purworejo Regency, Central Java. Thesis, UIN Walisongo. 